\title{
The Difference of Officialdom Status and the Performance of Islamic Education Teachers in the Private Madrasah Aliyah
}

\author{
Lian G. Otaya ${ }^{1}$, Sumarlin Adam ${ }^{2}$ \\ lianotaya82@iaingorontalo.ac.id ${ }^{1}$, sumarlin.adam@iaingorontalo.ac.id ${ }^{2}$
}

IAIN Sultan Amai Gorontalo, Gorontalo, Indonesia

\begin{abstract}
The officialdom status of teachers in Indonesia is divided into two kinds, this officialdom status is assumed as predictor variable which influences teachers' performance. Therefore, this research aims to know the difference of the officialdom status and the performance of Islamic education teachers in the private madrasah aliyah, especially in Gorontalo City. The research method used was quantitative research with an analytical approach. The data were collected through the observation, questionnaire, and document study. The data analysis was conducted by t-test sample independent test with the help from SPSS Program version 24.0. The result of the research showed there was no difference of the performance of civil servant teachers and non civil servant teachers. Although almost the majority of Islamic education teachers in private madrasah aliyah was not civil servant, but their performance was as good as the civil servant teachers, because they had positive perspectives about teacher as a noble and glorious profession and also there was an expectation that their status could be changed from non civil servant teacher to civil servant teacher.
\end{abstract}

Keywords: Officialdom Status, Performance, Islamic Education Teachers

\section{INTRODUCTION}

Teacher's performance is a complex concept and influenced by some factors such as teacher status that they had. The teacher status basically differentiates the social status to the teacher profession [1]. The teacher status plays an important role in improving the teachers' performance, because the status is strongly related to right and obligation as the consequences of being teacher and also related to the officialdom.

The officialdom of teacher in Indonesia is divided into permanent teacher (civil servant teacher) and non-permanent teacher (non civil servant teacher). Civil servant teacher is permanent teacher paid by the government under the Indonesia Ministry of Education and Culture or under the Indonesia Ministry of Religion. While, non civil servant teacher is non permanent teacher who has not become the candidate of civil servant like in some cases there are some kinds of ways to be mandated as the civil servants for non permanent teachers. Yet, there are also some non permanent teachers who were called as contract teacher and obtain payment from the local government. Furthermore, there were some teachers called as foundation permanent teachers who work and serve in the private school. The payment and salary are the responsible from the school. The non permanent teacher is paid for each lesson hour; even there are some teachers that teach without getting payment to become a civil servant from the honorer way or as the opportunity to pass the test for the general formation. 
Looking carefully for the officialdom status of teachers above, generally, it shows that the civil servant teachers teach based on the specification of their education background based on the appointment letter from the government and have monthly salary and allowance. Meanwhile, noncivil servant teachers teach flexibly based on the appointment letter from the headmaster and can replace other noncivil servant teachers when they cannot attend the class and also their salary is adjusted from the school funding. Therefore, between civil servant teacher and noncivil servant teacher, there is a different status, especially in the salary and prosperity. Whereas, the responsibility from that two kind of teachers to the school is the same [2]. This thing affects their performance in teaching.

Some countries in the western or eastern, such as in New York, teachers are paid about $\$ 3.000$ to meet the teachers' performance target [3]. In Texas, teachers are paid $\$ 6.000$ as the incentive for their performance, and it is expected can positively affect the students' learning result and their performance in teaching in the class [4]. In Chicago, Teacher Advancement Program (TAP) is implemented. In this program, only required teachers will obtain the salary as much $\$ 6,400$, if they are able to give contribution to the achievement of the students' success additional value (at school or school level) and show the good performance in the class observation assessment [5].

In Filipina, the new teacher is paid $145 \%$ from the average income, while in Indonesia at 2008 , the salary of junior high school teachers is only about $40 \%$ from the capita average income (UNESCO Institute of Statistics 2010). The difference is also huge, if it is compared with the salary of teachers in East Asia and Pacific. Converted in US Dolar, the salary of elementary school teachers in Indonesia is less than 1/3 of the salary of teachers in Malaysia and Philippines and also less than $1 / 2$ of the salary of teachers in Thailand. The salary of teachers in Indonesia shows the huge gap from the salary of teachers in Malaysia and Thailand. In Indonesia, a teacher obtains $\$ 1.002-\$ 3,022$ per year or only $50 \%$ of the gross domestic product (GDP) Per capita per kapita, according to the estimation of the United Nations Educational, Scientific and Cultural Organization (UNESCO). Teachers in philipines and Thailand obtain twice more than GDP per capita, and four times bigger than the salary of teachers in Indonesia [6]. Meanwhile, based on the data of non civil servant teachers in Indonesia at 2017, the numbers of non civil servant teachers in Indonesia are 721.124 from the total 3.015.315 of teachers. From that number, about 7000 of non civil servant teachers obtain the salary which is too far from the expectation. This thing is also supported from the report of the Education Efieciency Index, Indonesia is included to the one of the countries with very less appreciation for the performance of teachers in teaching. The salary of non civil servant teachers is only about Rp. 300.000 per month. Furthermore, the government of Indonesia has made various regulations and policies to increase the prosperity of teachers through the giving of sertification program in the form of the prosperity allowance for the teacher who has obtained the educator sertificate.

Non-civil servant teachers in public and private schools have quite complex problems including the honorarium earned on average under and failure in CPNS selection doesn't necessarily making worse because their have a good resilience [7]. Besides that, the economic problems of Non-civil servant teachers have not yet become the government's attention because their income has not yet been suitable with the responsibilities of teachers in schools. The problems faced by Non civil servant teachers are closely related to two things, they are the level of prosperity that is still low and uncertainty to be appointed as permanent teachers with Non civil servant status. The reality in the field found that the performance of Non civil servant teachers is better than the civil servant teachers. Similarly, on the contrary there are those who claim that the performance of civil servant teachers is better than non civil servant 
teachers. But there are also those who say there is no difference between the performance of civil servant teachers and Non civil servant teachers [8]. Including the teachers of Islamic education who teach in the Madrasah Aliyah.

Based on those problems, this study is designed to determine the differences in teachers' performance between civil servant teacher and non civil servant teacher. This research is important to solve the gap in the performance of teachers between the civil servant status and the Non civil servant status by giving the same treatment without any differences in terms of the prosperity and appreciation of their performance and being input for policy makers in improving the performance of Islamic education teachers. Especially in Private Madrasah Aliyah, most of the teachers are not civil servant. If the teacher teaches well in the class, it will be able to provide quality education for students.

\section{METHOD}

\section{A. The Research Design}

This study used a quantitative type of research with an expansive approach in obtaining information through the responses of each individual sample to the questions presented in the questionnaire. The design of the survey approach in this study adopted a descriptive quantitative research model to describe the description of the research variables based on the scores of each respondent, so that the perception of the characteristics and responses of respondents to the indicators assessed in each of the research variables studied was determined, aand also tried to find differences in teacher performance of Islamic education teachers, whether in the group of civil servant teachers or non civil servant teachers.

\section{B. Population and Sample}

The population of this research was all Senior Secondary School teachers in Gorontalo Province, with total of 2,862 teachers consisting of 1,997 civil servant teachers with details of 108 teachers serving as principals, 1,880 civil servants of the Department of Education and Culture, 11 civil servant teachers in the Ministry of Religion, 68 civil servant teachers placed to help the teaching parocss in the madrasah aliyah , 38 Foundation teachers and 757 non civil servant teachers with details of 2 additional teachers, 504 regional honorary teachers and 257 non-permanent teachers (Center For Educational Data and Statistics and Culture, 2016).

The samples of this rsearch were teachers in five Gorontalo City Private Madrasah Aliyah with total 44 teachers (MA. Nurul Yaqiin, MA. Al-Yusra, MA. Al-Khairaat, MA. AlHuda and MA. Muhammadiyah), using purposive sampling. The sample of teachers in this research had different characteristics in the number of female teachers more than the number of male teachers. From 44 teachers, there were 28 female teachers or $64 \%$ and 16 male teachers or $36 \%$. Furthermore, teachers with the civil servant status status were 11 teachers or $25 \%$ and teachers with Non civil servant status were 33 teachers or $75 \%$. Most of the teachers with undergraduate education, such as Strata 1 degree are 19 teachers or $43 \%$, and 9 teachers or 20\% have S2 education (Master degree), the remaining 16 teachers or 37\% have Diploma education. The sample of teachers in this research mostly had a working period at least 10 years. This was appropriate with the age and the position of teacher respondents who were senior teachers.

\section{The Data Collecting Technique}

The data in this research used primary and secondary data. Primary data were collected directly from respondents who were sampled using a questionnaire as the main instrument and observation as a supporting instrument. While secondary data were collected through the 
documentation studies to obtain the profiles of Islamic education teachers and reffering to teacher performance assessment documents based on the standard performance indicators used by Headmasters and Supervisors. The instrument used was the Teacher Performance Assessment Tool (APKG) consisting of APKG I Teacher's performance in learning planning and APKG II was used to assess teacher performance in the implementation of the learning process including the assessment conducted by the teacher in learning. APKG I involves assessing teacher performance in learning planning assessed from some indicators, they were: formulating learning objectives, developing and organizing materials, learning media, and learning resources, planning learning activity scenarios, designing classroom management, planning procedures, types, and preparing assessment tools, and documents lesson plan. APKG II intends to assess teacher performance in the implementation of learning assessed from some indicators indicators such as: managed learning spaces and facilities, conducted learning activities, managed class interactions, and conducted the process evaluations and final learning evaluations.

The procedure which was conducted in the data collection using a questionnaire was preceded by preparing instrument outlines, writing the instruments based on the outlines, reviewing the instrument items, testing the instruments in the field and analyzing the data, revising the instruments based on the results of analysis of trial data and conducting the measurements and interpreting the results. The procedure allowed to reduce the bias that occurred and also to avoid ambiguity before being used for the data collection.

The data were obtained from the questionnaire by using a Likert scale on a 1-5 scale of each item in the questionnaire. To ensure that all items used in the questionnaire were valid and consistent, the rsearchers proved validity of the data and estimated the reliability of the instrument. All items in the questionnaire were valid. While for the instrument reliability was used the internal consistency to check the condition of the instrument. It was done by calculating the Cronbach Alpha coefficient for all items from the questionnaire from the results of the test. The calculation results obtained 0.857, compared with the criteria recommended by the Alpha value $(\alpha) 0,70$. It showed that the instrument was reliable.

For the purposes of the data processing in this research, the data selection and classification were conducted first. The data had been collected through the distribution of questionnaires which were classified according to the groups of civil servant teachers and non civil servant teachers who were selected and examined to determine the completeness of the number and contents. The criteria used to select these instruments were: 1) filling instruments which were appropriate with the instructions listed on the instrument instructions sheet;2) all questions in each instrument were filled out and nothing was empty; 3) there were no instrument sheets which were lost or damaged.

\section{The Data Analysis}

The data in this study were analyzed by using descriptive statistics and inferential statistics. Descriptive statistical analysis was aimed to describe the basic characteristics of the data through the presentation of the data in the form of tables and graphs. While, the inferential statistics conducted different tests with independent testing $t$ test samples. This test was conducted to find out the difference in the average of the two different and unrelated groups, to find out the differences in the status of the civil servant group and the Non civil servant group on their performance. The data processing process was conducted by using the help of Microsoft Excel and SPSS programs (Statistical Package for Social Science) version 24.0 from computer programs. 


\section{RESULT}

The teacher status variable in this research were the civil servant teachers who were permanent teachers and were appointed as the civil servant by the Government or the Regional Government based on the prevailing laws and regulations. While, Non civil servant teachers were teachers who were appointed by principals / schools, foundations, regions or other legal entities that organized education units, based on the work agreements. This variable was a variable which was grouped into two categories, they were: the respondents with civil servant teacher status which were given code 1, then the respondents with Non civil servant teacher status were coded 2. To obtain a more detailed picture of the score obtained from the minimum and maximum scores from the data on the total score of the assessment results performance performed by headmasters and supervisors for each teacher both civil servant teacher status and Non civil servant status was presented in the form of the frequency distribution tables and histogram charts as followed.

TABEL I

THE DISTRIBUTION OF THE SCORE FREQUENCY OF TEACHER STATUS VARIABLE

\begin{tabular}{cccc}
\hline No & Score Interval & $\begin{array}{c}\text { Frequency } \\
(\mathbf{F})\end{array}$ & $\begin{array}{c}\text { Precentage } \\
(\mathbf{\%})\end{array}$ \\
\hline 1 & $163-172$ & 7 & 16 \\
\hline 2 & $154-162$ & 15 & 34 \\
\hline 3 & $146-153$ & 8 & 18 \\
\hline 4 & $138-145$ & 7 & 16 \\
\hline 5 & $130-137$ & 5 & 11 \\
\hline 6 & $122-129$ & 2 & 5 \\
\hline & Total & 44 & 100 \\
\hline
\end{tabular}

Table I showed that the highest score was 172 and the lowest score was 122 with the details of the distribution of teacher status variable scores from 44 respondents with civil servant status were 11 teachers and Non civil servant status with total 33 teachers who obtained the spread of the scores in the respondents with the scores of 122-129 with consisted of 2 Respondents (5\%), respondents with a score of 130-137 with total 5 respondents (11\%), respondents with the scores of 138-145 with total 7 respondents (16\%), the number of respondents with the scores of 146-153 with total 8 respondents (18\%), the number of respondents with a score of 154-162 with total 15 respondents (34\%) and the number of respondents with the scores of 163-172 with total 7 respondents (16\%). This thing showed that the majority of respondents' scores were in the range 154-162 with the highest frequency of $34 \%$ of the total respondents. For more details can be seen in Figure 1:

Fig. 1. Histogram The Score Frequer By observing carefully

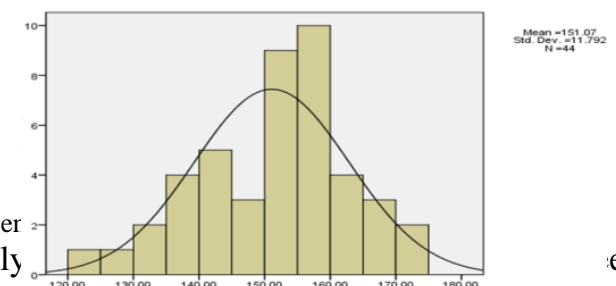

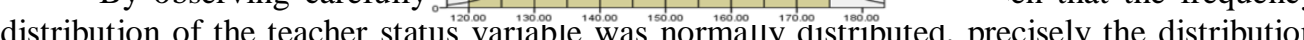
was in the middle position of the mean value of 151.07 and the standard deviation indicating deviation from the data was 11.79. The conclusion of the analysis of the description of teacher status variables consisting of the civil servant status and Non civil servant status and the 
interpretation of each grouping was analyzed from the descriptive statistics by using SPSS with the output obtained in table II:

TABEL II

DESCRIPTIVE STATISTICS OF TEACHER STATUS VARIABLE

\begin{tabular}{|l|r|r|}
\hline N Valid & Civil servant & $\begin{array}{c}\text { Non civil } \\
\text { servant }\end{array}$ \\
Mean & 11 & 33 \\
Missing & 22 & 0 \\
Median & $1.5336 \mathrm{E} 2$ & 150.3030 \\
Mode & 3.44640 & 2.08598 \\
Std. Deviation & $1.5800 \mathrm{E} 2$ & 152.0000 \\
Variance & 158.00 & $141.00^{\mathrm{a}}$ \\
Range & $1.14304 \mathrm{E} 1$ & 11.98302 \\
Minimum & 130.655 & 143.593 \\
Maximum & 36.00 & 50.00 \\
Sum & 129.00 & 122.00 \\
& 165.00 & 172.00 \\
& 1687.00 & 4960.00 \\
\hline
\end{tabular}

a. Multiple modes exist. The smallest value is shown

Table II showed the statistics descriptive data on teacher status variables based on civil servant and Non civil servant groupings obtained a description that for the civil servant status, the average score was 1.53 . The standard deviation was 1.143 with the lowest score was 129 and the highest score was 165 . The median obtained was 1.58 . The highest score or mode value was 158 . The diversity of the data was indicated by the variance of 130,655 . As for the Non civil servant status, the average score was 150, the standard deviation was 11.98 with the lowest score was 122 and the highest score was 172. The median obtained was 152 . The highest score or mode value was 141 . The diversity of data was indicated by the variance of 143,593.

For the variables of teacher performance were the scores obtained from the Islamic education teachers' performance assessment based on APKG I and APKG II. To obtain a more detailed description of the scores obtained from the minimum and maximum scores from the data on the number of teacher performance scores based on the results of the teacher performance scores with the civil servant and Non civil servant status was presented in the form of frequency distribution tables and histogram charts as followed.

TABLE III THE DISTRIBUTION OF THE SCORE FREQUENCY OF TEACHERS' PERFORMACE VARIABLES

\begin{tabular}{|c|c|c|c|}
\hline No & Score Interval & $\begin{array}{l}\text { Frequency } \\
\text { (F) }\end{array}$ & $\begin{array}{c}\text { Persentage } \\
(\%)\end{array}$ \\
\hline 1 & 164-175 & 9 & 20 \\
\hline 2 & $154-163$ & 14 & 32 \\
\hline 3 & 144-153 & 15 & 34 \\
\hline 4 & $134-143$ & 5 & 11 \\
\hline 5 & $124-133$ & 0 & 0 \\
\hline 6 & $115-124$ & 1 & 2 \\
\hline \multicolumn{2}{|r|}{ Total } & 44 & 100 \\
\hline
\end{tabular}


Table III showed that the highest score was 175 and the lowest score was 115 with the details of the distribution of teacher performance scores obtained from 44 respondents with the details of 11 people with the civil servant status and Non civil servant teachers with total total 33 people which and it was obtained the spread of scores that was the number of respondents with the scores of $115-124$ taken by 1 respondent $(0 \%)$, the scores of 124-133 with total 0 respondents $(0 \%)$, the scores of $134-143$ with total 5 respondents $(11 \%)$, the scores of $144-153$ with total 15 respondents (34\%), the scores of $154-163$ with total 14 respondents $(33 \%)$ and the scores of 164-175 with total 9 respondents (20\%). It showed that most respondents get scores in the range of 144-153 with the highest frequency of $34 \%$ from the total respondents. For more details, see figure 2 :

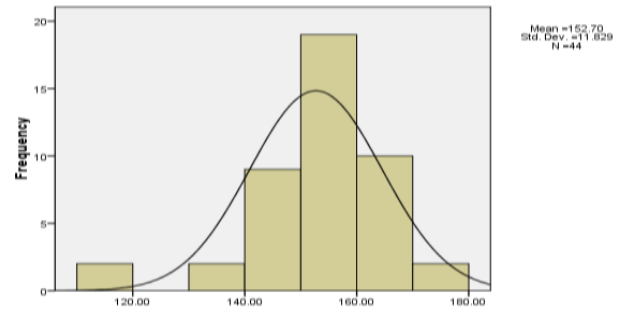

Fig. 2. The Histogram of Score Frequency of Teacher Variable Performance

By observing carefully the Figure 2 above, it was seen that the frequency distribution of teachers' performance was normally distributed, precisely the distribution was precisely in the middle position of the mean value of 152.70 and the standard deviation that showed the deviation from the data was 11.82 . The conclusion of the description analysis of the teachers' performance variables consisting of the civil servant teachers' performance and Non civil servant teachers' performance as presented in table IV.

TABEL IV

DESCRIPTIVE STATISTICS OF TEACHER STATUS VARIABLE

\begin{tabular}{|l|r|r|}
\hline & Civil servant & $\begin{array}{c}\text { Non civil } \\
\text { servant }\end{array}$ \\
\hline N Valid & 11 & 33 \\
Mean & 22 & 0 \\
Std. Error of Mean & $1.5336 \mathrm{E} 2$ & 152.1818 \\
Median & 3.44640 & 3.60257 \\
Mode & $1.5800 \mathrm{E} 2$ & 154.0000 \\
Std. Deviation & 158.00 & 154.00 \\
Variance & $1.14304 \mathrm{E} 1$ & 11.94837 \\
Range & 130.655 & 142.764 \\
Minimum & 36.00 & 46.00 \\
Maximum & 129.00 & 119.00 \\
Sum & 165.00 & 165.00 \\
\hline
\end{tabular}

Table IV showed the statistics descriptive data of teachers' performance variable based on the grouping of the performances of civil servant teachers and non civil servant teachers which the description that for the civil servant teachers' performance, the average score was 152. The standard deviation was 11.94 with the lowest score was 119 and the highest score 
was 165 . The Median obtained was 154 . The highest score or mode value was 154 . The diversity of the data was indicated by the variance of 142,764. Then, in the finding of the differences of the performances of civil servant teachers, the average score was 152, the standard deviation was 11.97 with the lowest score was 115 and the highest score was 175 . The median obtained was 153 . The most frequently appearing score or mode value was 153 . The diversity of data was indicated by the variance of 143,297. Furthermore, to find out whether the differences in the status of civil servant teachers and Non civil servant teachers affectd simultaneously the performance which was seen from the results of the calculation output as shown in table V:

TABEL V

\begin{tabular}{|c|c|c|c|c|c|c|}
\hline \multicolumn{7}{|c|}{ Coefficients ${ }^{\mathrm{a}}$} \\
\hline \multirow{2}{*}{\multicolumn{2}{|c|}{ Model }} & \multicolumn{2}{|c|}{$\begin{array}{c}\text { Unstandardized } \\
\text { Coefficients }\end{array}$} & \multirow{2}{*}{\begin{tabular}{|c|}
$\begin{array}{c}\text { Standardized } \\
\text { Coefficients }\end{array}$ \\
Beta \\
\end{tabular}} & \multirow{2}{*}{$\mathrm{t}$} & \multirow{2}{*}{ Sig. } \\
\hline & & B & Std. Error & & & \\
\hline & (Constant) & 16.105 & 28.323 & & .569 & .584 \\
\hline & $\mathrm{X}$ & .887 & .184 & .849 & 4.817 & .001 \\
\hline
\end{tabular}

a. Dependent Variable: Y

Table $\mathrm{V}$ showed the regression coefficient of 0.887 which meant that each addition of one value to the teacher status variable $(\mathrm{X})$ gave the improvement of the scores as much 0.887 in the teachers' performance. Furthermore, the results of the coefficient of determination that showed the the effect of the differences in teacher status on teacher performance, can be seen in the results of the SPSS output summary model in the column value of R-Square in table VI:

TABEL VI MODEL SUMMARY ${ }^{\mathbf{B}}$

Model Summary

\begin{tabular}{|c|c|c|c|c|}
\hline Model & $\mathrm{R}$ & R Square & $\begin{array}{c}\text { Adjusted R } \\
\text { Square }\end{array}$ & $\begin{array}{c}\text { Std. Error of the } \\
\text { Estimate }\end{array}$ \\
\hline 1 & $.849^{\mathrm{a}}$ & .720 & .689 & 6.65863 \\
\hline
\end{tabular}

a. Predictors: (Constant), $\mathrm{X}$

b. Dependent Variable: Y

Table VI showed the value of the R-Squarenya was 0.720 or $72 \%$. This meant that the performance of Islamic education teachers was influenced by their status as both teachers with civil servant status and Non civil servant status as much $72 \%$, the remaining $28 \%$ were influenced by other variables. Hypothesis testing results in a regression coefficient of 0.887 which was positive and greater than the significant level of $0.05(0.887>0.05)$ so that it was concluded that the teacher's status had a positive effect on the performance of Islamic education teachers in Private Madrasah Aliyah. In testing the hypothesis for the regression model with $t$ test, the degree of freedom or also called as the Degree of Freedom (df) was determined by the formula $\mathrm{df}=\mathrm{n}-\mathrm{k}$. Where $\mathrm{n}=$ the numbers of observations or respondents while $\mathrm{k}=$ the numbers of variables (free and bound. In the regression analysis to test this hypothesis using a two-way hypothesis testing or 2-sided test at a significance level of 0.05 with the number of respondents $\mathrm{n}=44$ and the number of variables $\mathrm{k}=2$, then obtained $\mathrm{df}=$ $44-2=42$ by testing the hypothesis 2 sides, they were the value of $\alpha$ (alpha) $=0.05: 2=0.025$, the results obtained for $t$ table was 2.021. When compared to the Unstandartdized Coeffecients 
column, the value of tcount $=4,817$ While the table $=2.021$, $t$ count $>t$ table, the teachers' status had a significant effect on their performance.

Therefore, it was concluded that the status of teachers both civil servant and Non non civil servant had a positive and significant effect on the performance of slamic education teachers in Private Madrasah Aliyah. To prove whether the differences in the performance of teachers with civil servant and Non civil servant status were tested, the analysis was done by using the independent sample $t$ test. This test was conducted to find the average difference from the two different and unrelated groups, those were the differences in the status of civil servant and Non civil servant on the performance of the output obtained as presented in table VII: performance of the output obtained as presented in table VII:

TABEL VII GROUP STATISTICS

\begin{tabular}{|cc|r|r|r|c|}
\hline & Group & $\mathrm{N}$ & Mean & $\begin{array}{c}\text { Std. } \\
\text { Deviation }\end{array}$ & $\begin{array}{c}\text { Std. Error } \\
\text { Mean }\end{array}$ \\
\hline Score & ASN & 11 & 1.533 & 11.43042 & 3.44640 \\
& NON ASN & 33 & 1.503 & 11.98302 & 2.08598 \\
\hline
\end{tabular}

Based on table VII showed that there was a difference in the value of performance between teachers with the civils ervant status and teachers with Non civil servant status, The average values of civil servant teachers' performance $(1,533)$ was higher than the Non civil servant teachers' performance $(1,503)$ although the difference was not too large with a difference of 0,03 . Furthermore, based on the independent sample $t_{\text {test }}$ showed that the value of the levene test for the homogeneity was the same, then it was used the first line that was the value of $t_{\text {count }} 0.742$ in DF 42. DF in $t$ test is $N-2$, that was in this case 44-2 = 42 obtained $t$ table $=2,021$. This $t_{\text {count }}$ value was compared with $t_{\text {table }}$ in DF 18 and probability 0.05 , as presented in table VIII:

TABEL VIII

\begin{tabular}{|c|c|c|c|}
\hline \multicolumn{4}{|c|}{ INDEPENDENT SAMPLES TEST } \\
\hline & & \multicolumn{2}{|l|}{ Score } \\
\hline & & $\begin{array}{l}\text { Equal variances } \\
\text { assumed }\end{array}$ & $\begin{array}{l}\text { Equal variances not } \\
\text { assumed }\end{array}$ \\
\hline \multirow{2}{*}{$\begin{array}{c}\text { Levene's Test for } \\
\text { Equality of } \\
\text { Variances }\end{array}$} & $\mathrm{F}$ & .050 & \\
\hline & Sig. & .825 & \\
\hline \multirow[b]{5}{*}{$\begin{array}{l}\text { t-test for Equality of } \\
\text { Means }\end{array}$} & $\mathrm{T}$ & .742 & .760 \\
\hline & Df & 42 & 17.917 \\
\hline & $\begin{array}{l}\text { Sig. (2- } \\
\text { tailed) }\end{array}$ & 462 & .457 \\
\hline & $\begin{array}{c}\text { Mean } \\
\text { Difference }\end{array}$ & 306.061 & 306.061 \\
\hline & $\begin{array}{l}\text { Std. Error } \\
\text { Difference }\end{array}$ & 412.696 & 402.852 \\
\hline
\end{tabular}

Table VIII showed that the value of $t_{\text {count }}$ was 0.742 compared to $t_{\text {table }}$ value of 2.021 where $t_{\text {count }}<t_{\text {table }}(0.742<2.021)$, meaning that there was no difference in the influence of officialdom status on the performance of teachers in the Islamic School in the district of Bone Pantai, Bone Bolango Regency. The second way was to see the value of Sig (2 tailed) or $\mathrm{p}$ value. In the table above the $\mathrm{p}$ value was 0.462 where $>0.05$. Because $>0.05$, there was no statistically significant or significant difference in the 0.05 probability. The value of the mean difference or the mean of the two groups was shown in the Mean Difference column, which 
was 3.06061, both of which were positive, meaning that the teachers with civil servant status had a higher Mean than teachers with Non civil servant status, although the difference was small.

Therefore, from the findings of the research, it was concluded that there was no difference in the performance of islamic education teachers in the Private Madrasah Aliyah with the civil servant status and the performance of teachers with the Non civil servant status. Although the status was not the same, but in conducting their duties and responsibilities, there was no difference.

\section{DISCUSSIONS}

The findings of the research showed the status of teachers both civil servant and Non civil servant had a positive and significant influence on the performance of Islamic education teachers in the Private Madrasah. It showed that with the status of civil servant or non civil servant, their performance was $72 \%$. Then, for teachers who were not a civil servant, they were possible to be appointed as a permanent teacher or the civil servant, because this indicator was one of the motivating factors for teachers with Non civil servant status to improve their performance, there was hope that the performance was an added value for teachers with the Non civil servant status to be recruited as a civil servant teacher. Meanwhile, for teachers with the civil servant status by maintaining and improving their performance so that they can work well, it was also possible that they were promoted to rise to the position of headmaster or vice headmasters or other positions. According to Tehseen (2015) teacher performance could be maintained if they were satisfied with their work, because job satisfaction caused them to have superior levels of performance and only teachers with good performance who were able to provide the good education for their students [9]. Teacher performance also described the competencies that teachers had and was not only needed in achieving didactic tasks based on the curriculum, but also in developing students' competencies in learning [10].

Based on the findings also obtained an illustration that there was no significant difference in the performance of teachers with the civi servant status and Non civil servant status, although there was a difference in the value of performance between teachers with the civil servant status and Non civil servant teachers. Where the average value of civil servant teachers' performance was higher than that of teachers with Non civil servant status, although the difference was not too large and not statistically significant. Regarding the improvement of the performance of Islamic education teachers with the non civil servant status in the Private Madrasah Aliyah, they had not been able to fulfill their expectations well especially in the terms of prosperity. But it did not decrease their motivation in showing good performance. The results of observations and interviews were also known to be very difficult for Islamic education teachers who had a Non civil servant status to get the civil servant teacher status and were given the confidence to hold the positions. It was seen from the number of Islamic education teachers in the field with Non civil servant status as many as 33 people, far more than the number of Islamic education teachers with the civil servant status which were only 11 people, where the civil servant teacher was the majority of teachers who was holding the positions in each madrasah as the headmaster.

The finding of the research indicated that although the Islamic education teachers in the Private Madrasah Aliyah in Gorontalo City were not a civil servant, they had a performance that was not much different from the performance of teachers with the civil servant status, because they had a positive view of the teaching profession as noble and proud and high hopes for the changing of their status from Non civil servant teachers to be recruited as the civil 
servant teachers. This was in line with the findings of Balkis \& Masykur (2016) that although teachers were only had honorary status, they enjoyed their profession at the time [7]. The work motivation that existed in the individuals had the great effect on the individual's job satisfaction. The failure in the selection of civil servant did not necessarily make it worse. This was influenced by the perspective of this profession. They saw the teacher as a work that was noble, proud, pleasing, and brought blessing. Patience, high gratitude, and social support also helped the three subjects in reducing negative emotions so that it was easier to achieve satisfaction in life and work. Even though they were still Non civil servant teacher, they were reluctant to give up their profession because they felt comfortable being a teacher. They decided to establish themselves, continued to serve and survived to become a teacher no matter what the circumstances. The common factors that affected them were self esteem, personality, work, income, belief (religion), family, social contact, event, and activity. Another factor was high gratitude, social support that came from family and friends, and the work motivation that had an impact on the job satisfaction.

For that, a more complete study on this issue was needed to assist the policy makers in improving the performance of the Islamic education teachers, especially in the Private Madrasah Aliyah, where most of the teachers were not a civil servant. As the weaknesses of this study, it was only focusing on the status of the teachers concerned as one of the variables that affected their performance, while there were many variables that influenced it and not only limited to the teacher status such as: teacher competence, work motivation, work discipline, job satisfaction and others. It provided an opportunity for other researchers to do more reveal the problems.

\section{CONCLUSSION}

The finding of the research showed that in general there was no difference in the performance of the Islamic education teachers in the Private Madrasah Aliyah with the civil servant status and the performance of teachers with the non civil servant status. Although the status was not the same, but in conducting their duties and responsibilities, there was no difference. To further improve the performance of Non civil servant teachers, there was a need to increase their prosperity in accordance with the performance that was given to Madrasah. Furthermore, the income earned by Non civil servant teachers was very low and often late. Unlike the case with teachers who had the civil servant status whose salary had been determined based on the class which could not be intervened again and supplemented by the certification allowances for educators for those who were certified. Besides that, it was necessary to seek more acceptance or recruitment of Non civil servant teachers through a better selection mechanism by using a number of requirements that were oriented towards optimizing performance. The Ministry of Religion as the responsible institution needed to formulate further about the conditions for determining Non civil servant teachers as permanent teachers mainly on the basis of the work achievement criteria that refered to the teacher's abilities and expertise in each work unit, so that with the change in the status from Non civil servant teachers being the civil servant teacher gave a strong motivation for them to improve their performance to be better for day by day.

\section{REFERENCES}

[1] V. Symeonidis, The Status of Teachers and the Teaching Profession A study of Report by, no. March. Belgium: Education International Research Institute, 2015.

[2] C. Meiza, "PERBEDAAN KEBAHAGIAAN PADA GURU DIFFERENCES HAPPINESS ON CIVIL SERVANTS," J. Ilm. Psikol., vol. 9, no. 2, pp. 132-141. 
[3] R. G. Fryer, "Teacher Incentives and Student Achievement : Evidence from New York City Public Schools," vol. 31, no. 2, pp. 373-407, 2013.

[4] M. G. Springer, D. F. Mccaffrey, S. F. Burns, L. S. Hamilton, and B. Stecher, "Team Pay for Performance : Experimental Evidence From the Round Rock Pilot Project on Team Incentives," Educ. Eval. Policy Anal., vol. 34, no. 4, pp. 367-390, 2012.

[5] T. Dee and J. Wyckoff, "Incentives, Selection, and Teacher Performance: Evidence from IMPACT," Camridge.

[6] M. C. Chang, S. Shaeffer, S. Al-Samarrai, A. B. Ragatz, J. de Ree, and R. Stevenson, Teacher Reform in Indonesia. Washington DC: The World Bank, 2014.

[7] A. S. Balkis and A. M. Masykur, "Memahami Subjective Well-Being Guru Honorer Sekolah Dasar Negeri ( Sebuah Studi Kualitatif Fenomenologis )," J. Empati, vol. 5, no. April, pp. 223-228, 2016.

[8] S. M. Nastiti, "Perbedaan kinerja guru berdasarkan status kepegawaian pns dan non pns di sma negeri se-kabupaten rembang skripsi," Universitas Negeri Semarang, 2016.

[9] S. Tehseen, "Factors Influencing Teachers ' Performance and Retention," Mediterr. J. Soc. Sci., vol. 6, no. 1, pp. 233-244, 2015.

[10] L. G. Otaya, B. Kartowagiran, and H. Retnawati, "Construct validity pedagogy competency instrument of teaching and learning practice program (TLPP ) students: Unidimensional confirmatory factor analysis," Int. J. Adv. Appl. Sci., vol. 5, no. 8, pp. 24-33, 2018. 